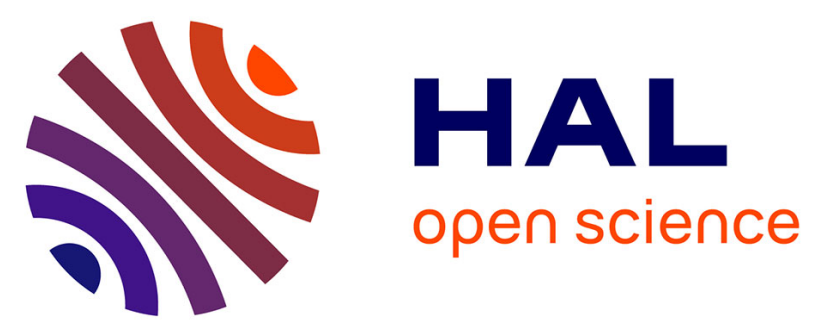

\title{
Assessment of the nitrogen management strategy using an optical sensor for irrigated wheat
}

Bijay-Singh, R. Sharma, Jaspreet-Kaur, Mangi Jat, Kent Martin, Yadvinder-Singh, Varinderpal-Singh, Chandna, Om Choudhary, Rajeev

Gupta, et al.

\section{To cite this version:}

Bijay-Singh, R. Sharma, Jaspreet-Kaur, Mangi Jat, Kent Martin, et al.. Assessment of the nitrogen management strategy using an optical sensor for irrigated wheat. Agronomy for Sustainable Development, 2011, 31 (3), pp.589-603. 10.1007/s13593-011-0005-5 . hal-00930523

\section{HAL Id: hal-00930523 \\ https://hal.science/hal-00930523}

Submitted on 1 Jan 2011

HAL is a multi-disciplinary open access archive for the deposit and dissemination of scientific research documents, whether they are published or not. The documents may come from teaching and research institutions in France or abroad, or from public or private research centers.
L'archive ouverte pluridisciplinaire HAL, est destinée au dépôt et à la diffusion de documents scientifiques de niveau recherche, publiés ou non, émanant des établissements d'enseignement et de recherche français ou étrangers, des laboratoires publics ou privés. 


\title{
Assessment of the nitrogen management strategy using an optical sensor for irrigated wheat
}

\author{
Bijay-Singh • R. K. Sharma • Jaspreet-Kaur • Mangi L. Jat • Kent L. Martin • \\ Yadvinder-Singh • Varinderpal-Singh • Parvesh Chandna • Om Parkash Choudhary • \\ Rajeev K. Gupta • Harmit S. Thind • Jagmohan-Singh • Harminder S. Uppal • \\ Harmandeep S. Khurana • Ajay-Kumar • Rajneet K. Uppal • Monika Vashistha • \\ William R. Raun • Raj Gupta
}

Accepted: 30 July 2010 / Published online: 15 March 2011

(C) INRA and Springer Science+Business Media B.V. 2011

\begin{abstract}
Blanket fertilizer nitrogen $(\mathrm{N})$ recommendations for large irrigated wheat tracts lead to low N-use efficiency due to field-to-field variability in soil $\mathrm{N}$ supply and seasonal variability in yield. To achieve high $\mathrm{N}$ use efficiency, a sitespecific $\mathrm{N}$ management strategy using GreenSeeker ${ }^{\mathrm{TM}}$ optical sensor was evaluated. We conducted seven field experiments
\end{abstract}

Bijay-Singh $(\bowtie) \cdot$ Jaspreet-Kaur $\cdot$ Yadvinder-Singh $\cdot$

Varinderpal-Singh • O. P. Choudhary $\cdot$ R. K. Gupta $\cdot$ H. S. Thind

Jagmohan-Singh $\cdot$ H. S. Uppal $\cdot$ Ajay-Kumar $\cdot$ R. K. Uppal

M. Vashistha

Department of Soil Science, Punjab Agricultural University, Ludhiana, India

e-mail: bijaysingh20@hotmail.com

\section{R. K. Sharma}

Directorate of Wheat Research,

Karnal, India

M. L. Jat

PDCSR,

Modipuram, India

\section{K. L. Martin}

Southwest Area Extension, Kansas State University,

Garden City, KS 67846, USA

P. Chandna $\cdot$ R. Gupta

Rice-Wheat Consortium-CIMMYT,

NASC Complex, Pusa,

New Delhi, India

\section{H. S. Khurana}

International Plant Nutrition Institute (IPNI), West India Program,

Pune, India

W. R. Raun

Department of Plant and Soil Sciences,

Oklahoma State University,

Stillwater, OK 74078, USA during 2004-2006 at three locations to define relationships between in-season sensor measurements and yield of wheat and to know whether response of wheat to fertilizer $\mathrm{N}$ can be estimated by sensor measurements. During 2005-2007, four field experiments were conducted to assess the sensor-based $\mathrm{N}$ management strategy and to work out prescriptive $\mathrm{N}$ management to be followed prior to applying sensorguided fertilizer dose. We observed robust relationships between in-season sensor-based estimates of yield at Feekes 5-6 and 7-8 stages and actual wheat yields. Response of wheat to fertilizer $\mathrm{N}$ defined by the sensor was highly correlated with harvest response index. Sensor-guided fertilizer $\mathrm{N}$ applications resulted in high yield levels and high N-use efficiency. Application of $90 \mathrm{~kg} \mathrm{~N} \mathrm{ha}^{-1}$ at planting or in two equal doses at planting and crown root initiation stage was the appropriate prescriptive fertilizer $\mathrm{N}$ management. This study reveals that high $\mathrm{N}$-use efficiency in irrigated wheat can be achieved by replacing blanket fertilizer recommendation by an optical sensor-based $\mathrm{N}$ management strategy consisting of applying moderate amount of fertilizer $\mathrm{N}$ at planting and crown root initiation stages and sensor-guided fertilizer $\mathrm{N}$ dose at Feekes $5-6$ or $7-8$ stages of wheat.

Keywords Indo-Gangetic Plain · Irrigated wheat · Nitrogen management $\cdot$ Response index $\cdot$ GreenSeeker optical sensor $\cdot$ Potential yield

\section{Introduction}

Traditionally, farmers in the Indo-Gangetic Plains of South Asia and elsewhere apply $\mathrm{N}$ uniformly as a blanket recommendation for large regions in wheat growing tracts. Many farmers often use uniform rates of $\mathrm{N}$ fertilizers based 
on expected yields (yield goal) that could be inconsistent from field-to-field and year-to-year depending on factors that are difficult to predict prior to fertilizer application. Also, farmers often apply fertilizer $\mathrm{N}$ in doses much higher than the blanket recommendations to ensure high crop yields. Large temporal and field-to-field variability of soil $\mathrm{N}$ supply restricts efficient use of $\mathrm{N}$ fertilizer when broadbased blanket recommendations are used (Adhikari et al. 1999; Dobermann et al. 2003). Under such situations, inseason site-specific $\mathrm{N}$ management can effectively replace the blanket fertilizer $\mathrm{N}$ recommendations for achieving high $\mathrm{N}$-use efficiency. Application of fertilizer $\mathrm{N}$ that corresponds to the spatial variability of the $\mathrm{N}$ need of crops should not only lead to increased $\mathrm{N}$-use efficiency but also to reduced possibility of fertilizer N-related environmental pollution (Khosla and Alley 1999). For example, according to Kranz and Kanwar (1995) as much as $70 \%$ of the total N leached comes from as little as $30 \%$ of the total field area. With $50 \%$ or more operational land holdings in South Asia having less than 2 ha (remaining $30-40 \%$ up to 10 ha) (Indian Agricultural Statistics Research Institute 2007), it seems that high fertilizer N-use efficiency can be improved through field-specific fertilizer $\mathrm{N}$ management because it takes care of both spatial and temporal variability in soil $\mathrm{N}$ supply. Successful strategies will comprise of management options based on location-specific fertilizer $\mathrm{N}$ requirements of crops according to year-to-year variations in climate (particularly solar radiation) and spatial as well temporal variations of indigenous soil N supplies (Giller et al. 2004). Although generally good correlations with grain yield have been observed with methods based on soil tests and laboratory analyses of tissue samples to predict cereal $\mathrm{N}$ needs during vegetative growth stages (Fox et al. 1989; Hong et al. 1990; Magdoff et al. 1990; Justes et al. 1997; Lemaire and Gastal 1997), these are time-consuming, cumbersome, and expensive. Tissue tests are also of less value for the support of decisions on $\mathrm{N}$ supplementation than indicators that are directly related to measurement of leaf and canopy greenness (Schröder et al. 2000).

Dynamic $\mathrm{N}$ management requires rapid assessment of leaf $\mathrm{N}$ content-a sensitive indicator of changes in crop $\mathrm{N}$ demand during the growing season. The chlorophyll or SPAD meter (SPAD-502, Minolta, Ramsey, NJ, USA), and its inexpensive and simple alternative, the leaf color chart can quickly and reliably monitor relative greenness of leaf as an indicator of leaf $\mathrm{N}$ status. These tools have helped in developing real-time $\mathrm{N}$ management strategies for rice (Ladha et al. 2005) but do not take into account photosynthetic rates or the biomass production and expected yields for working out fertilizer $\mathrm{N}$ requirements. Application of optical sensors in agriculture is increasing rapidly through measurement of visible and near-infrared (NIR) spectral response from plant canopies to detect $\mathrm{N}$ stress (Peñuelas et al. 1994; Ma et al. 1996; Raun et al. 2001). Chlorophyll contained in the palisade layer of the leaf controls much of the visible light $(400-720 \mathrm{~nm})$ reflectance as it absorbs between $70 \%$ and $90 \%$ of all incident light in the red wavelength bands (Campbell 2002). Reflectance of the NIR electromagnetic spectrum (720-1,300 nm) depends upon the structure of mesophyll tissues, which reflects as much as $60 \%$ of all incident NIR radiation (Campbell 2002). Spectral vegetation indices such as the normalized difference vegetation index (NDVI) have been shown to be useful for indirectly obtaining information such as photosynthetic efficiency, productivity potential, and potential yield (Peñuelas et al. 1994; Thenkabail et al. 2000; Ma et al. 2001; Raun et al. 2001; Báez-González et al. 2002) and have been found to be sensitive to leaf area index, green biomass (Peñuelas et al. 1994), and photosynthetic efficiency (Aparicio et al. 2002). Raun et al. (2001) found expected yield as determined from NDVI to show a strong relationship with the actual grain yield in winter wheat. Using NDVI measurements of wheat at different times during crop growth period, Raun et al. $(2001,2002)$ developed concepts of response index and potential yield, and these were used to define a fertilizer nitrogen algorithm for working out the fertilizer $\mathrm{N}$ requirement in winter wheat based on expected yields as well as achievable greenness of the leaves. Raun et al. (2002) showed that prediction of wheat response to $\mathrm{N}$ applications guided by optical sensor was positively correlated to measured $\mathrm{N}$ response and increased $\mathrm{N}$-use efficiency. Recently, Li et al. (2009) evaluated optical sensorbased $\mathrm{N}$ management in winter wheat in China by conducting 30 on-farm experiments. Averaged across site-years, sensorbased strategy and farmer's practices produced similar yields but applied 67 and $372 \mathrm{~kg} \mathrm{~N} \mathrm{ha}^{-1}$, respectively.

In the Indo-Gangetic Plains in northwestern India wheat is generally grown under assured irrigation conditions. Following blanket recommendations, $\mathrm{N}$ fertilizers are applied at the rate of 120 (in the state of Punjab) or 150 (in the states of Haryana, Uttar Pradesh) $\mathrm{kg} \mathrm{N} \mathrm{ha}^{-1}$ in two equal split doses at planting and at crown root initiation stages. The second dose coincides with first irrigation event around 21 days after planting. This being a blanket recommendation for the region consists of applying $\mathrm{N}$ doses at planting and crown root initiation stage (Meelu et al. 1987) high enough to meet the crop requirement as well as to compensate the losses of $\mathrm{N}$ via ammonia volatilization, denitrification and leaching (Bijay-Singh and Yadvinder-Singh 2003). To achieve high fertilizer use efficiency, prescriptive $\mathrm{N}$ doses at planting and crown root initiation stage (or first irrigation stage) can be moderately reduced provided $\mathrm{N}$ needs of the crop taking into account the field-to-field and temporal variability are worked out using a suitable criteria to apply a corrective fertilizer dose coinciding with second or third irrigation event. It cannot 
only ensure site-specific $\mathrm{N}$ management in wheat but also avoid over application of fertilizer $\mathrm{N}$.

In the present investigation, we developed relationships between NDVI measurements made by GreenSeeker optical sensor after applying one or two prescriptive doses of $\mathrm{N}$ and yield of wheat. Using these relations and response indices, fertilizer $\mathrm{N}$ doses to be applied at Feekes $5-6$ or Feekes 7-8 stage of irrigated spring wheat were worked out. The major objective of the present study was to evaluate optical sensor-based $\mathrm{N}$ management in irrigated wheat vis-à-vis prevalent blanket fertilizer $\mathrm{N}$ recommendations in the Indo-Gangetic Plains. Since GreenSeekerguided $\mathrm{N}$ application could be made only once, it was important to define the appropriate set of prescriptive $\mathrm{N}$ applications at planting and crown root initiation stage which preceded it. Thus, other major objective of the study was to define the prescriptive $\mathrm{N}$ management scenarios based on application of fertilizer $\mathrm{N}$ doses at planting and crown root initiation stage of the crop with which optical sensor-guided fertilizer $\mathrm{N}$ applications can be combined for improved fertilizer N-use efficiency. Different combinations of prescriptive and corrective $\mathrm{N}$ management scenarios were therefore evaluated vis-à-vis blanket recommendations for $\mathrm{N}$ in the region to suggest a viable and better alternative to current completely prescriptive approach for $\mathrm{N}$ management in wheat. In the irrigated wheat in the IndoGangetic Plains in the northwestern India, the application of fertilizer $\mathrm{N}$ doses along with 2 nd or 3rd irrigation events should almost coincide with Feekes 5-6 and 7-8 stages of the crop.

\section{Materials and methods}

\subsection{Site description}

Field experiments were conducted at Ludhiana $\left(30^{\circ} 56^{\prime} \mathrm{N}\right.$, $\left.75^{\circ} 52^{\prime} \mathrm{E}\right)$, Karnal $\left(29^{\circ} 42^{\prime} \mathrm{N}, 77^{\circ} 02^{\prime} \mathrm{E}\right)$, and Modipuram $\left(29^{\circ} 40^{\prime} \mathrm{N}, 77^{\circ} 46^{\prime} \mathrm{E}\right)$ in the Indo-Gangetic Plain in northwestern India. The three sites have subtropical climates. Mean monthly temperature and rainfall for the sites are shown in Fig. 1. Soils were mildly alkaline loamy sands (Typic Ustipsamment) at the Punjab Agricultural University farm, Ludhiana, mildly alkaline sandy loam (Typic Ustochrept) at the Directorate of Wheat Research farm, Karnal, and alkaline sandy loams (Typic Ustochrept) at the farms of Project Directorate for Cropping Systems Research, Modipuram. Initial soil samples collected from each field experiment were mixed, combined by field replication, air dried, sieved, and analyzed for physical and chemical characteristics. The $\mathrm{pH}$ and electrical conductivity $\left(\mathrm{H}_{2} \mathrm{O}, 1: 2\right)$, total and mineral $\mathrm{N}$, bicarbonateextractable (Olsen) $\mathrm{P}$, exchangeable $\mathrm{K}$, cation exchange
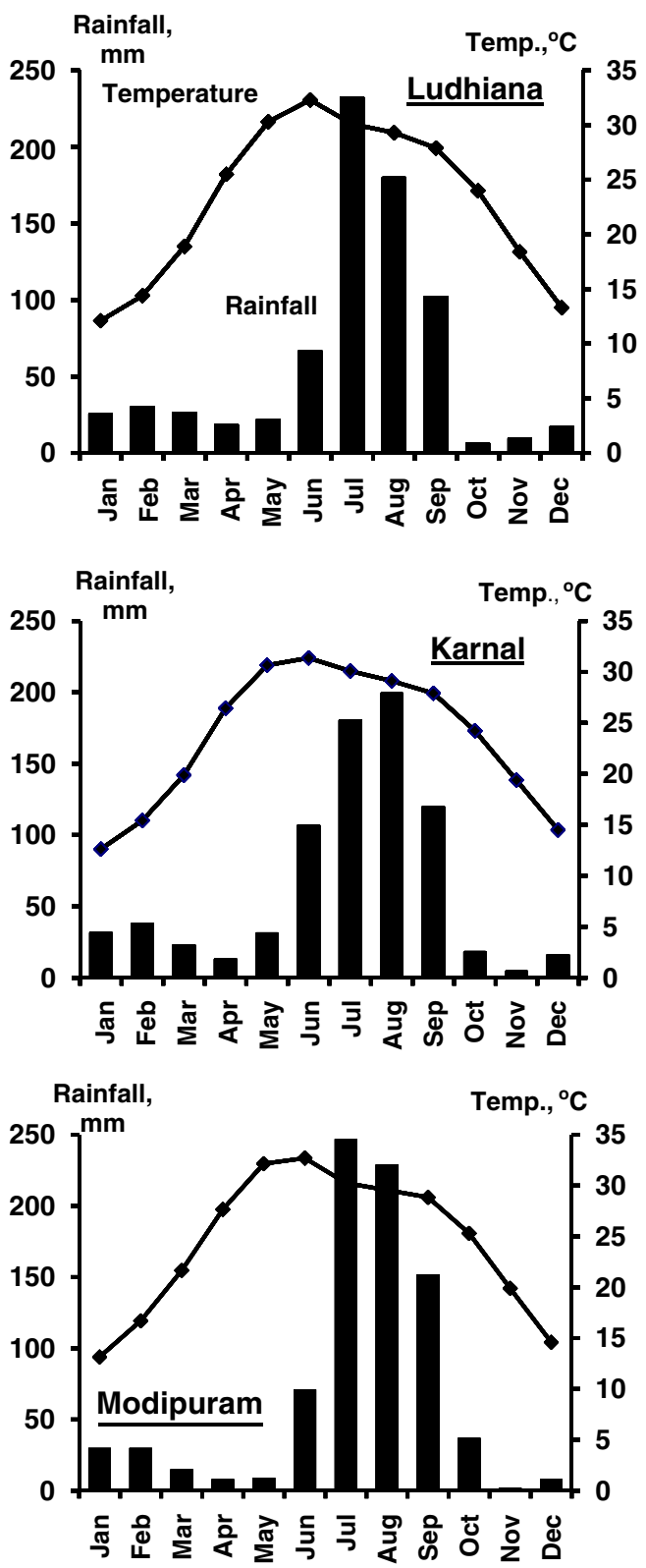

Fig. 1 Average monthly mean temperature and monthly rainfall (average of last 25 years) at Ludhiana, Karnal, and Modipuram, India

capacity with ammonium acetate at $\mathrm{pH} 7$, and particle size by the hydrometer method are shown in Table 1 .

2.2 Experiments for developing relationships for predicting yield potential of wheat from in-season optical sensor measurements (calibration experiments)

Field experiments were conducted in three wheat seasons (2004-2005 to 2006-2007) at Ludhiana, Karnal, and Modipuram. During 2005-2006 and 2006-2007 wheat seasons, the treatments consisted of application of fertilizer $\mathrm{N}$ as urea at $60,120,180$, and $240 \mathrm{~kg} \mathrm{~N} \mathrm{ha}^{-1}$ applied at planting of wheat and 60,120 , and $180 \mathrm{~kg} \mathrm{~N} \mathrm{ha}^{-1}$ in two 


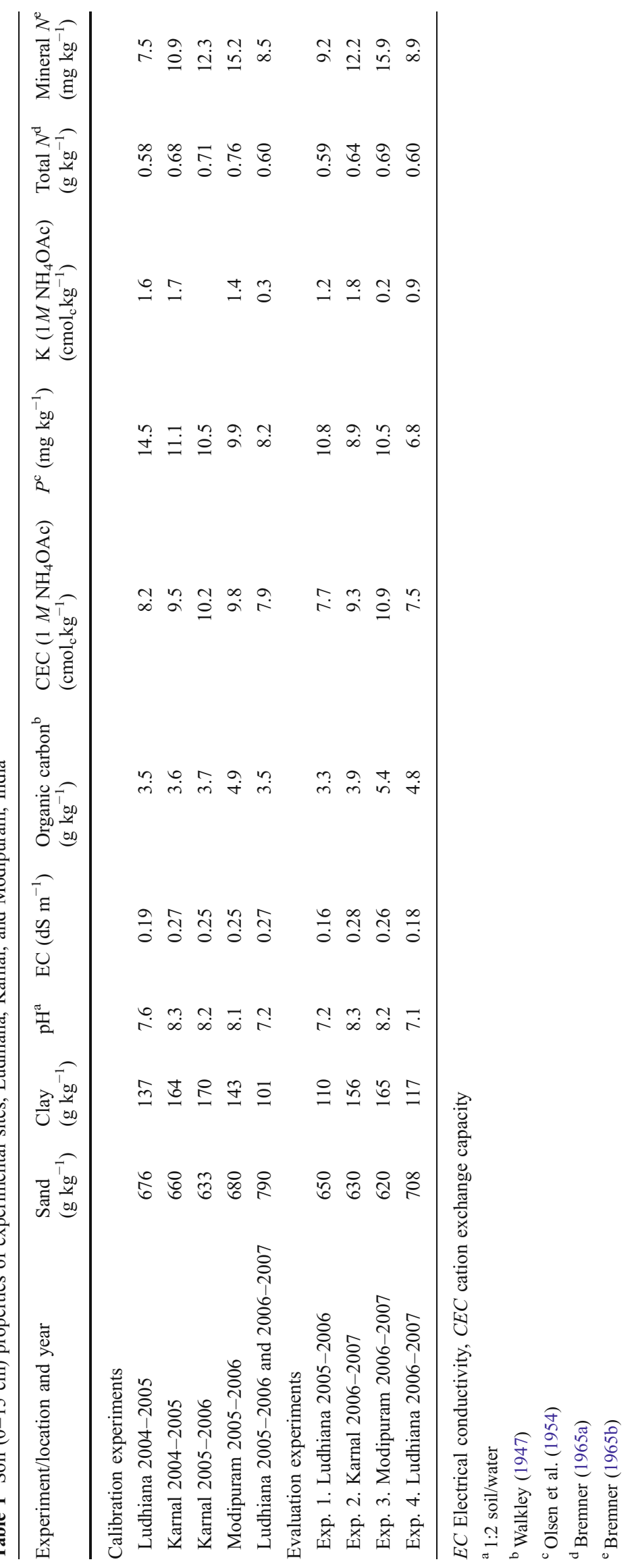


equal split doses, one at planting and the other at crown root initiation stage that occurs around 21 days after planting and coincides with first irrigation. A no-N control plot was also maintained. During 2004-2005 wheat season, two on-going field experiments at Ludhiana and one ongoing experiment at Karnal were used to generate data to develop relationships for in-season estimation of wheat yields. In these experiments, doses of urea-N varying from 0 to $90 \mathrm{~kg} \mathrm{~N} \mathrm{ha}^{-1}$ were applied in two equal doses at planting and at the crown root initiation stage of wheat. During 2006-2007 at Ludhiana, two experiments were conducted with zero-till sown wheat; one with rice straw mulch and the other without mulch. Details of the experiments such as planting date, sensing date, and variety are given in Table 2 . All field experiments were laid out in a randomized complete block design with three or four replications.

During the month of January in 2005, 2006, and 2007, spectral reflectance readings were taken at the time of applying second and third irrigations to wheat crop (the first irrigation was applied at crown root initiation stage 3 weeks after planting of crop) coinciding with Feekes (Large 1954) growth stages 5-6 and 7-8. Sensing dates in different experiments are listed in Table 1. Sensor measurements were taken from treatments with varying levels of $\mathrm{N}$ nutrition within each replication. Spectral reflectance expressed as NDVI was measured using a handheld GreenSeeker ${ }^{\mathrm{TM}}$ optical sensor unit (NTech Industries Incorporation, Ukiah, CA, USA). The unit senses a $0.6 \times 0.1 \mathrm{~m}^{2}$ area when held at a distance of approximately $0.6-1.0 \mathrm{~m}$ from the illuminated surface. The sensed dimensions remain approximately constant over the height range of the sensor. The sensor unit has self-contained illumination in both the red ([656 nm with $\sim 25 \mathrm{~nm}$ full width half magnitude (FWHM)) and NIR (774 with $~ 25 \mathrm{~nm}$ FWHM) bands (http://www.ntechindustries.com/datasheets. php, confirmed on 01 September 2008). The device uses a patented technique to measure the fraction of the emitted light in the sensed area that is returned to the sensor (crop reflectance) and calculates NDVI as:

$\mathrm{NDVI}=\frac{F_{\mathrm{NIR}}-F_{\mathrm{Red}}}{F_{\mathrm{NIR}}+F_{\mathrm{Red}}}$

where $F_{\mathrm{NIR}}$ and $F_{\text {Red }}$ are respectively the fractions of emitted NIR and red radiation reflected back from the sensed area. The sensor outputs NDVI at a rate of ten readings per second. The sensor was passed over the crop at a height of approximately $0.9 \mathrm{~m}$ above the crop canopy and oriented so that the $0.6 \mathrm{~m}$ sensed width was perpendicular to the row and centered over the row. With advancing stage of growth, sensor height above the ground increased proportionally. Travel velocities were at a slow walking speed of approximately $0.5 \mathrm{~ms}^{-1}$ resulting in NDVI readings averaged over distances of $0.05 \mathrm{~m}$.

In-season estimated yield proposed by Raun et al. (2002) as the measure of the daily accumulated biomass from the time of planting to the day of sensing was calculated by dividing the NDVI data by the number of growing degree days $(\mathrm{GDD})>0\left(\mathrm{GDD}=\left(T_{\min }+T_{\max }\right) / 2-4.4^{\circ} \mathrm{C}\right.$, where $T_{\min }$ and $T_{\max }$ represent daily ambient low and high temperatures) from planting to sensing. The yield potential with no additional fertilization $\left(\mathrm{YP}_{0}\right)$ was calculated using an empirically derived function relating in-season estimated yield to yield potential as: $\mathrm{YP}_{0}=a^{*}(\text { estimated yield })^{\mathrm{b}}$.

In five experiments carried out at Ludhiana, Karnal, and Modipuram during 2005-2006 and 2006-2007 wheat seasons, fertilizer $\mathrm{N}$ doses as high as 180 or $240 \mathrm{~kg} \mathrm{~N} \mathrm{ha}^{-1}$ were applied. Thus, maximum wheat yields could be

Table 2 Some details of the optical sensor calibration experiments in which optical sensor readings (NDVI) and wheat grain yield data were collected

\begin{tabular}{|c|c|c|c|c|c|c|c|}
\hline Location & Year & $\begin{array}{l}\text { Fertilizer } \mathrm{N} \text { treatments } \\
\left(\mathrm{kg} \mathrm{N} \mathrm{ha}^{-1}\right)\end{array}$ & Tillage & Planting date & Sensing date & Harvest date & Variety \\
\hline Ludhiana & 2004-2005 & $0,30,45,60$, and 90 & Conventional till & 08 Nov 2004 & 13 Jan 2005 & 08 Apr 2005 & PBW343, PDW274 \\
\hline Karnal & $2004-2005$ & 0,60 , and 90 & Conventional till & 23 Nov 2004 & $\begin{array}{l}12 \text { Jan } 2005 \\
23 \text { Jan } 2005\end{array}$ & 12 Apr 2005 & PBW343, HD2687 \\
\hline Ludhiana & $2005-2006$ & $0,60,120,180$, and 240 & Conventional till & 04 Nov 2005 & $\begin{array}{l}\text { 03 Jan } 2006 \\
\text { 13 Jan } 2006\end{array}$ & 12 Apr 2006 & PBW343, PDW274 \\
\hline Karnal & $2005-2006$ & $0,60,120,180$, and 240 & Conventional till & 11 Nov 2005 & $\begin{array}{l}\text { 09 Jan } 2006 \\
\text { 23 Jan } 2006\end{array}$ & 08 Apr 2006 & PBW343, HD2687 \\
\hline Modipuram & $2005-2006$ & $0,60,120,180$, and 240 & Conventional till & 05 Nov 2005 & $\begin{array}{l}\text { 04 Jan } 2006 \\
\text { 16 Jan } 2006\end{array}$ & 12 Apr 2006 & PBW343, HD2687 \\
\hline Ludhiana & $2006-2007$ & $0,60,120,180$, and 240 & $\begin{array}{l}\text { No till, rice straw } \\
\text { mulched }\end{array}$ & 02 Nov 2006 & $\begin{array}{l}\text { 03 Jan } 2007 \\
15 \text { Jan } 2007\end{array}$ & 11 Apr 2007 & PBW343 \\
\hline Ludhiana & $2006-2007$ & $0,60,120,180$, and 240 & No till & 02 Nov 2006 & $\begin{array}{l}\text { 03 Jan } 2007 \\
\text { 15 Jan } 2007\end{array}$ & 11 Apr 2007 & PBW343 \\
\hline
\end{tabular}


recorded in these experiments. It allowed computation of response (to fertilizer $\mathrm{N}$ ) indices $\mathrm{RI}_{\mathrm{NDVI}}$ and $\mathrm{RI}_{\text {Harvest }}$ (Mullen et al. 2003; Johnson and Raun 2003) as:

$$
\begin{aligned}
\mathrm{RI}_{\mathrm{NDVI}}= & (\mathrm{NDVI} \text { of the highest yield treatment }) / \\
& (\mathrm{NDVI} \text { of the test plot })
\end{aligned}
$$

$\mathrm{RI}_{\text {Harvest }}=$ (maximum yield $) /($ yield of the test plot $)$

\subsection{Experiments for evaluating optical sensor-based $\mathrm{N}$ management (evaluation experiments)}

In all, four field experiments were conducted to evaluate optical sensor-based $\mathrm{N}$ management in wheat vis-à-vis blanket recommendation for the region. During 2005-2006 wheat season, an experiment was conducted at Ludhiana whereas during 2006-2007 experiments were located at Modipuram, Karnal, and Ludhiana. Blanket recommendations for $\mathrm{N}$ management in wheat in northwestern India consisting of applying half of the total dose of 120 (Ludhiana) or 150 (Karnal and Modipuram) $\mathrm{kg} \mathrm{N} \mathrm{ha}^{-1}$ at planting and remaining half at the crown root initiation stage coinciding with first irrigation event 3-4 weeks after planting, constituted the reference treatments for evaluating the GreenSeeker-based N management. Since fertilizer N application to wheat has to coincide with an irrigation event, GreenSeeker-based N management treatments were planned to determine fertilizer $\mathrm{N}$ applications to wheat at Feekes 5-6 or Feekes 7-8 stage with different doses of $\mathrm{N}$ applied as prescriptive $\mathrm{N}$ management at planting and at crown root initiation stage. Also, Feekes 5-6 and Feekes 7-8 stages almost coincide with 2 nd and 3 rd irrigation events and relationships between in-season estimated yield and potential yield of wheat at these stages have been worked out. The treatments in the four experiments as listed in Tables 4, 5, 6, and 7 were laid out in randomized complete block design with three replications. Two sets of treatments consisting of applying prescriptive dose of $\mathrm{N}$ either only at planting or at both planting and at crown root initiation stages were tested to define the prescriptive fertilizer $\mathrm{N}$ application strategies compatible with an optical sensor-guided $\mathrm{N}$ application at 2nd or 3rd irrigation stage. Dates on which fertilizer $\mathrm{N}$ was applied corresponding to different growth stages of wheat are listed in Table 3.

In all the four experiments, an $\mathrm{N}$-rich strip was established by applying $200 \mathrm{~kg} \mathrm{~N}^{-1}$ in split doses to ensure that nitrogen was not limiting. The NDVI measurements from the $\mathrm{N}$ rich strip $\left(\mathrm{NDVI}_{\mathrm{NRICH}}\right)$ and the test plots $\left(\mathrm{NDVI}_{\mathrm{TEST}}\right)$ were used to calculate response index (RI) to fertilizer N (Johnson and Raun 2003) as per Eq. 2. The N-rich strips were characterized by the highest NDVI values. As advocated by Raun et al. (2002) the yield of the test plot achievable by applying additional fertilizer $\mathrm{N}$ $\left(\mathrm{YP}_{n}\right)$ was estimated as the product of $\mathrm{YP}_{0}$ and $\mathrm{RI}_{\mathrm{NDVI}}$. The $\mathrm{N}$ fertilizer algorithm to compute fertilizer $\mathrm{N}$ to be applied using GreenSeeker optical sensor (Raun et al. 2002) is based on determining the difference in estimated $\mathrm{N}$ uptake between $\mathrm{YP}_{n}$ and $\mathrm{YP}_{0}$. It was done by estimating the mean $\mathrm{N}$ content of the grain at harvest $(1.85 \% \mathrm{~N}$ for spring wheat grown in Indo-Gangetic Plains of South Asia; in Experiment 1 a value of $1.6 \%$ was used) and multiplying this number by $\mathrm{YP}_{n}$ and $\mathrm{YP}_{0}$, respectively. The difference in $\mathrm{N}$ uptake between $\mathrm{YP}_{0}$ and $\mathrm{YP}_{n}$ was then divided by efficiency factor (taken as 0.5 to be reasonably achievable under South Asian conditions; Singh et al. 2007) to work out the fertilizer $\mathrm{N}$ dose as:

Fertilizer $\mathrm{N}$ dose $=\frac{1.85 \times\left(\mathrm{YP}_{n}-\mathrm{YP}_{0}\right)}{100 \times 0.5}$

In this equation, $\mathrm{YP}_{n}$ and $\mathrm{YP}_{0}$ are expressed in $\mathrm{kg} \mathrm{ha}^{-1}$ so as to calculate fertilizer dose in $\mathrm{kg} \mathrm{N} \mathrm{ha}^{-1}$.

The values of $\mathrm{YP}_{0}$ used in fertilizer algorithm for computing fertilizer $\mathrm{N}$ doses to be applied in experiments conducted in 2005-2006 and 2006-2007 were based on inseason estimated yield $-\mathrm{YP}_{0}$ relationships developed from data collected from experiments conducted up to 2004 2005 and 2005-2006, respectively.

\subsection{Crop management}

Wheat was planted in rows $20 \mathrm{~cm}$ apart in 16.8 to $24 \mathrm{~m}^{2}$ plots on dates as indicated in Tables 2 and 3. Prior to seeding, the land was plowed twice to about 20 -cm depth

Table 3 Crop management details for the four field experiments conducted to evaluate optical sensor-based $\mathrm{N}$ management in wheat in India

\begin{tabular}{lllll}
\hline Crop management attribute & $\begin{array}{l}\text { Exp. 1. Ludhiana } \\
\text { 2005-2006 }\end{array}$ & $\begin{array}{l}\text { Exp. 2. Karnal } \\
\text { 2006-2007 }\end{array}$ & $\begin{array}{l}\text { Exp. 3. Modopuram } \\
\text { 2006-2007 }\end{array}$ & $\begin{array}{l}\text { Exp. 4. Ludhiana } \\
\text { 2006-2007 }\end{array}$ \\
\hline Date of planting & 28 Oct 2005 & 09 Nov 2006 & 10 Nov 2006 & 04 Nov 2006 \\
Crown root initiation stage, first irrigation & 19 Nov 2005 & 30 Nov 2006 & 02 Dec 2006 & 03 Dec 2006 \\
Feekes 5-6 stage, 2nd irrigation & 29 Dec 2005 & 03 Jan 2007 & 29 Dec 2006 & 03 Jan 2007 \\
Feekes 7-8 stage, 3rd irrigation & 23 Jan 2006 & 22 Jan 2007 & 19 Jan 2007 & 29 Jan 2007 \\
Harvesting & 10 Apr 2006 & 11 Apr 2007 & 09 Apr 2007 & 19 Apr 2007 \\
\hline
\end{tabular}


and leveled. After seeding with a seed-cum-fertilizer drill, a plank was dragged over the plots to cover the seed. All $\mathrm{P}$ (26 kg P ha ${ }^{-1}$ as $\left.\mathrm{Ca}\left(\mathrm{H}_{2} \mathrm{PO}_{4}\right)_{2}\right)$ and $\mathrm{K}\left(25 \mathrm{~kg} \mathrm{~K}^{-1}\right.$ as $\left.\mathrm{KCl}\right)$ were drilled below the seed at sowing. The basal dose of $\mathrm{N}$ per treatment was mixed in the soil just before sowing. In the 2006-2007 seasons at Ludhiana, two experiments were conducted for developing a relationship between in-season estimated yield and $\mathrm{YP}_{0}$ when wheat was sown after the harvest of rice crop under zero-till conditions. In these experiments, soil was not tilled after harvesting and wheat was planted using a zero-till seed-cum-fertilizer drill. In one of the experiments, rice straw was removed, while in the other $6 \mathrm{Mg} \mathrm{ha}^{-1}$ rice straw was allowed to remain in the field as mulch.

Four to five irrigations were applied at crown root initiation stage, Feekes 5-6, Feekes 7-8, flowering/booting, and grain-filling stages (depending upon rainfall events and climate) using both well and canal water. The dates of irrigation-cum-fertilizer application in four experiments conducted to evaluate GreenSeeker-guided $\mathrm{N}$ management vis-à-vis blanket recommendation are given in Table 3. The fertilizer $\mathrm{N}$ dose at planting of wheat was mixed with the soil. Both prescriptive and optical sensor-guided fertilizer $\mathrm{N}$ doses in the standing crop were uniformly hand broadcasted. Weeds, pests, and diseases were controlled as required.

Crops were harvested by hand at ground level at maturity on dates listed in Tables 2 and 3. Grain and straw yields were determined from an area $\left(8-13.2 \mathrm{~m}^{2}\right)$ located at the center of each plot. Grains were separated from straw using a plot thresher, dried in a batch grain dryer, and weighed. Grain moisture was determined immediately after weighing, and subsamples were dried in an oven at $65^{\circ} \mathrm{C}$ for $48 \mathrm{~h}$. Grain weight for wheat was expressed at $120 \mathrm{~g} \mathrm{~kg}^{-1}$ water content. Straw weights were expressed on oven-dry basis.

\subsection{Plant sampling and analysis}

Grain and straw subsamples were dried at $70^{\circ} \mathrm{C}$ and finely ground to pass through a $0.5 \mathrm{~mm}$ sieve. Nitrogen content in grain and straw was determined by digesting the samples in sulfuric acid followed by analysis for total $\mathrm{N}$ by a microKjeldahl method (Yoshida et al. 1976). The $\mathrm{N}$ in grain plus that in straw was taken as the measure of total $\mathrm{N}$ uptake.

\subsection{Data analysis}

Data generated from the four experiments conducted for evaluating the optical sensor-based $\mathrm{N}$ management were analyzed following analysis of variance using IRRISTAT version 5.0 (International Rice Research Institute, Philippines) and mean comparisons were performed based on least significant difference test at 0.05 probability level. The data generated from the calibration experiments were used to fit relationships between in-season estimated yield and $\mathrm{YP}_{0}$. Power functions of the type $\mathrm{YP}_{0}=a^{*}(\text { estimated yield })^{\mathrm{b}}$ and coefficients of determination $\left(R^{2}\right)$ were determined using MS EXCEL (Microsoft Corporation, Redland, CA, USA).

The N-use efficiency measures - recovery efficiency (RE), agronomic efficiency (AE), and physiological efficiency (PE) as described by Baligar et al. (2001) were computed as follows:

$$
\begin{aligned}
& \mathrm{RE}(\%) \\
& =\frac{(\text { total } \mathrm{N} \text { uptake in } \mathrm{N} \text { fertilized plot }- \text { total } \mathrm{N} \text { in no N plot }) \times 100}{\text { (quantity of } \mathrm{N} \text { fertilizer applied in } \mathrm{N} \text { fertilized plot })}
\end{aligned}
$$

where $\mathrm{N}$ uptake is the total $\mathrm{N}$ uptake in grain and straw.

$$
\begin{aligned}
& \mathrm{AE} \mathrm{kg} \text { grain } / \mathrm{kg} \mathrm{N} \text { applied } \\
& =\frac{(\text { grain yield in } \mathrm{N} \text { fertilized plot }- \text { grain yield in no } \mathrm{N} \text { plot })}{\text { (quantity of } \mathrm{N} \text { fertilizer applied in } \mathrm{N} \text { fertilized plot) }}
\end{aligned}
$$

$\mathrm{PE}$ (kg grain/kg N uptake)

$$
=\frac{(\text { grain yield in } \mathrm{N} \text { fertilized plot }- \text { grain yield in no } \mathrm{N} \text { plot })}{(\text { total } \mathrm{N} \text { uptake in } \mathrm{N} \text { fertilized plot }- \text { total } \mathrm{N} \text { uptake in no } \mathrm{N} \text { plot })}
$$

\section{Results and discussion}

\subsection{Predicting yield potential of wheat from in-season} optical sensor measurements

Data from Karnal, Ludhiana, and Modipuram generated in different years using different cultivars of wheat grown in tilled or zero-tilled soil and by applying fertilizer $\mathrm{N}$ levels either as whole basal or in two split doses were plotted as $x-y$ graph between in-season estimated yield and grain yield. Figure 2 shows these relationships for wheat at Feekes 5-6 stage. With wheat planting dates ranging from 02 November to 23 November and sensing dates ranging from 02 January to 23 January, a value of $R^{2}$ as high as 0.61 suggest that wheat yields can be predicted fairly accurately as early as Feekes 5-6 stage when first node appears on the wheat plant and second irrigation becomes due. The relationship turned out to be even more robust $\left(R^{2}=0.76\right)$ at Feekes 7-8 stage when data were available from even more number of experiments than for Feekes 5-6 stage (Fig. 3). At Feekes 7-8 stage, wheat crop demands irrigation again and a dose of fertilizer can also be applied along with the irrigation.

The concept of in-season estimated yield as developed by Raun et al. (2002) is unique as it provides an estimate of the yield potential $\left(\mathrm{YP}_{0}\right)$ of the particular area without additional $\mathrm{N}$ fertilizer (i.e., what the field would yield, all 


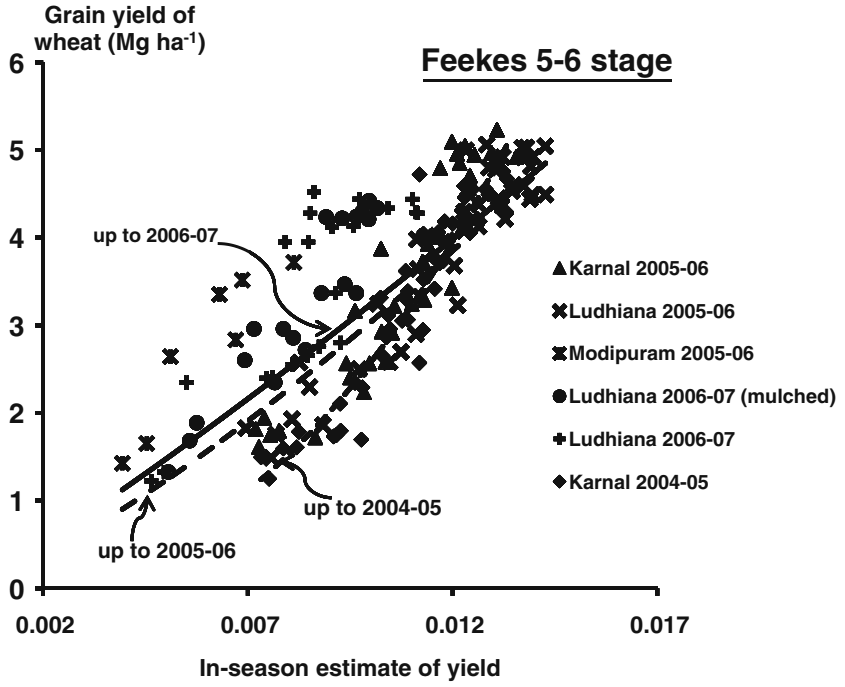

Fig. 2 Relationships between in-season estimate of yield and potential grain yield of irrigated wheat at Feekes 5-6 stage. $R^{2}=0.90$ (up to 2004-2005), 0.66 (up to 2005-2006), and 0.61 (up to 20062007). Relationship between in-season estimated yield $(x)$ and potential yield $(y)$ up to 2006-2007: $y=602.47 x^{1.1348}$

factors being equal, without any additional fertilizer applied). In fact, a robust relationship between in-season estimated yield (computed from NDVI data collected by GreenSeeker optical sensor) and yield potential constitutes the first step in determining fertilizer doses to be applied for correcting in-season $\mathrm{N}$ deficiencies in wheat. The estimated yield-potential yield functions ought to be unique for different geographic regions and irrigation practices. The results clearly indicate that for irrigated wheat as it is grown

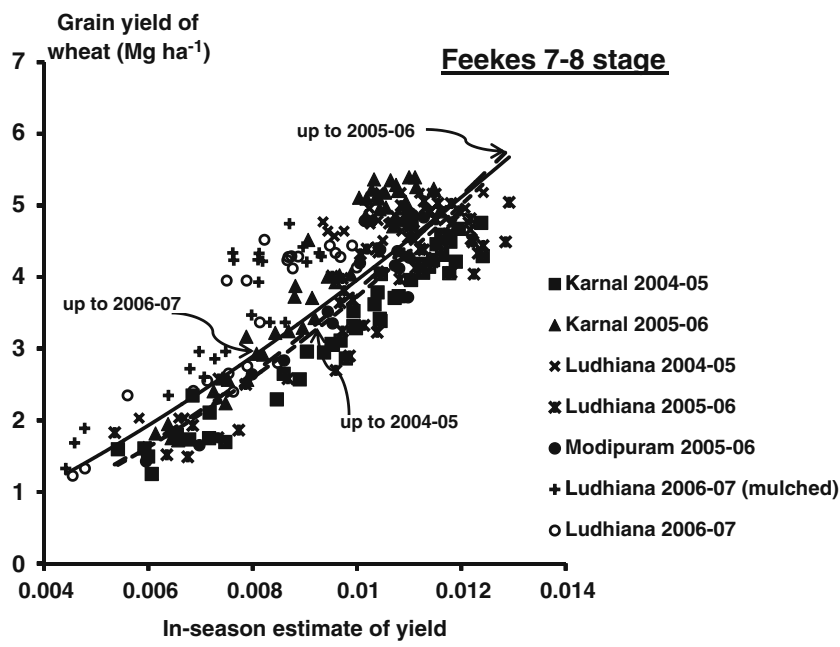

Fig. 3 Relationships between in-season estimate of yield and potential grain yield of irrigated wheat at Feekes 7-8 stage. $R^{2}=0.84$ (up to 2004-2005), 0.83 (up to 2005-2006), and 0.76 (up to 20062007). Relationship between in-season estimated yield $(x)$ and potential yield $(y)$ up to 2006-2007: $y=2581 x^{1.4072}$ in the western Indo-Gangetic Plains in the South Asia, biomass produced per day was a reliable predictor of grain yield. It was despite the fact that there exist so many uncontrollable variables (rainfall, planting date, temperature, etc.) from planting to sensing having potential to adversely affect the relationships between in-season estimated yield and $\mathrm{YP}_{0}$. Thus, relatively good fit of the estimated yield- $\mathrm{YP}_{0}$ relations as shown in Figs. 2 and 3 strongly support the argument that yield potential can indeed be predicted but the potential yield may not be realized because post-sensing condition could adversely impact the final grain yield.

Differences from yield prediction equations formulated using the data collected up to 2004-2005, 2005-2006, and 2006-2007 (Figs. 2 and 3) from different locations did not differ substantially when compared with each other. Only exception seems to be the relationship for Feekes 5-6 stage in 2004-2005 (Fig. 2); it was based on data collected from only one experiment conducted in Karnal. This suggests that it is possible to establish reliable yield potential prediction from at least 2 years of field data provided these were generated from enough number of sites. Decrease in regression significance $\left(R^{2}\right)$ was expected for relationships based on data collected up to 2004-2005, 2005-2006, and 2006-2007 because these were based on increasing number of data sets.

\subsection{Relationship between $\mathrm{R}_{\mathrm{INDVI}}$ and $\mathrm{RI}_{\text {Harvest }}$}

Estimating the amount of fertilizer $\mathrm{N}$ to be applied as per the need of crop in a given year not only depends upon estimation of a $\mathrm{YP}_{0}$, but also on the extent to which the crop will respond to additional fertilizer N. Pioneering work of Johnson and Raun (2003) provided the concept of a response index ( $\mathrm{RI}_{\mathrm{NDVI}}$ ) to quantify the later. The $\mathrm{RI}_{\mathrm{NDVI}}$ allowed estimation of the yield level that can be expected by applying additional $\mathrm{N}$. The inclusion of the N-rich strip reduces variability in the $\mathrm{N}$ fertilization optimization algorithm caused by localized weather and soil conditions by normalizing the output for the specific site. Johnson and Raun (2003) found that $\mathrm{RI}_{\mathrm{NDVI}}$ measured as ratio of NDVI of the $\mathrm{N}$ rich strip and that of test plot was positively correlated with ratio of yield in the $\mathrm{N}$ rich strip and that in the test plot. Figure 4 shows plots of $\mathrm{RI}_{\mathrm{NDVI}}$ versus $\mathrm{RI}_{\text {Harvest }}$ at Feekes 5-6 and Feekes 7-8 stages of wheat based on data collected from the calibration experiments. High values of the $R^{2}$ between $\mathrm{RI}_{\mathrm{NDVI}}$ and $\mathrm{RI}_{\text {Harvest }}$ at both the growth stages of wheat indicate that the in-season response index based on optical sensor readings is a viable method for identifying the field locations where the potential to respond to additional fertilizer $\mathrm{N}$ exists. Mullen et al. (2003) obtained similar relationships between $\mathrm{RI}_{\mathrm{NDVI}}$ and $\mathrm{RI}_{\text {Harvest }}$ with data recorded at different growth stages of winter wheat in 23 experiments. 

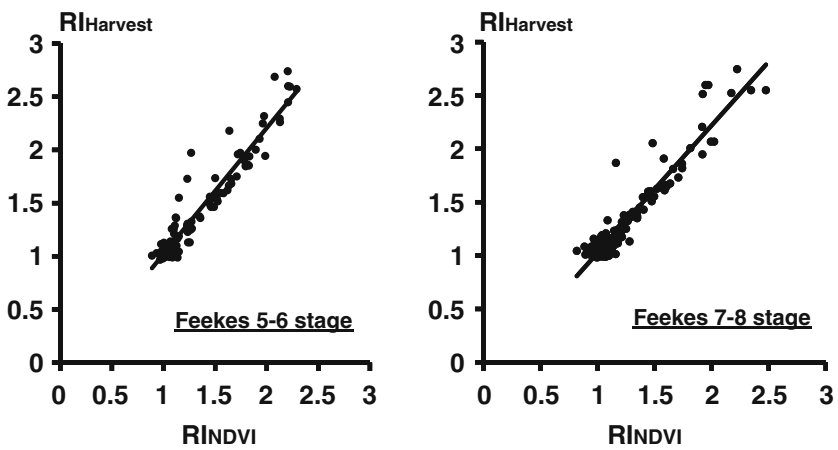

Fig. 4 Relationship between RINDVI (response index computed by in-season measurement of NDVI) and RIHarvest (response index determined from grain yield data at the harvest of the crop) in experiments conducted at Ludhiana, Karnal, and Modipuram during $2005-2006\left(y=1.186 x-0.165 ; R^{2}=0.91\right)$ and 2006-2007 $(y=1.945 x-$ $\left.0.170 ; R^{2}=0.90\right)$ wheat seasons

3.3 Estimating fertilizer $\mathrm{N}$ dose using optical sensor for correcting in-season $\mathrm{N}$ deficiency

Predicting the yield of the test plot with additional fertilizer $\left(\mathrm{YP}_{n}\right)$ allows quantification of the amount of fertilizer $\mathrm{N}$ to be applied, and this is accomplished by obtaining the product of $\mathrm{YP}_{0}$ and $\mathrm{RI}_{\mathrm{NDVI}}$. Using $\mathrm{YP}_{n}$ and $\mathrm{YP}_{0}$, the amount of additional $\mathrm{N}$ fertilizer required was determined by taking the difference in estimated $\mathrm{N}$ uptake between $\mathrm{YP}_{n}$ and $\mathrm{YP}_{0}$ and an efficiency factor (Raun et al. 2002). Since response to fertilizer $\mathrm{N}$ application depends not only upon supply of nonfertilizer $\mathrm{N}$ (mineralized from soil organic matter, deposited through rainfall or through irrigation etc.), the amount of fertilizer $\mathrm{N}$ applied at planting and at crown root initiation stage (along with first irrigation event) also determined $\mathrm{RI}_{\mathrm{NDVI}}$. As shown in Tables 4, 5, 6, and 7, prescriptive $\mathrm{N}$ management in the form of applying different doses of fertilizer $\mathrm{N}$ at planting and the crown root initiation stage of wheat and whether optical sensorbased $\mathrm{N}$ management was practiced at Feekes $5-6$ or Feekes 7-8 stage greatly influenced the dose of fertilizer $\mathrm{N}$ to be applied following $\mathrm{N}$ fertilizer optimization algorithm. In general, amount of $\mathrm{N}$ to be applied at Feekes 5-6 stage as guided by optical sensor turned out be less than that worked out at Feekes 7-8 stage. Data pertaining to $\mathrm{YP}_{0}$ and $\mathrm{RI}_{\mathrm{NDVI}}$ as listed in Tables 4, 5, 6, and 7 reveal that for similar application of fertilizer $\mathrm{N}$ at planting and the crown root initiation stage, higher optical sensor-guided fertilizer $\mathrm{N}$ doses at Feekes 7-8 stage were due to higher $\mathrm{RI}_{\mathrm{NDVI}}$ values recorded at this stage than at the Feekes 5-6 stage. Obviously due to passage of more time after applying the

Table 4 Evaluation of GreenSeeker-based N management in wheat (cultivar PBW 343) at Ludhiana, India during 2005-2006

\begin{tabular}{|c|c|c|c|c|c|c|c|c|c|c|c|c|}
\hline \multirow[t]{2}{*}{ Treatment } & \multicolumn{5}{|c|}{ Fertilizer $\mathrm{N}$ application $\left(\mathrm{kg} \mathrm{N} \mathrm{ha}^{-1}\right)$} & \multirow[t]{2}{*}{$\mathrm{YP}_{0}\left(\mathrm{Mg} \mathrm{ha}^{-1}\right)$} & \multirow[t]{2}{*}{ RI } & \multirow{2}{*}{$\begin{array}{l}\text { Grain yield } \\
\left(\mathrm{Mg} \mathrm{ha}^{-1}\right)\end{array}$} & \multirow{2}{*}{$\begin{array}{l}\text { Total N uptake } \\
\left(\mathrm{kg} \mathrm{ha}^{-1}\right)\end{array}$} & \multirow[t]{2}{*}{$\mathrm{AE}$} & \multirow[t]{2}{*}{$\mathrm{RE}(\%)$} & \multirow[t]{2}{*}{$\mathrm{PE}$} \\
\hline & $\begin{array}{l}\text { Basal at } \\
\text { sowing }\end{array}$ & $\begin{array}{l}\text { CRI, 1st } \\
\text { irrigation }\end{array}$ & $\begin{array}{l}\text { Feekes 5-6 } \\
\text { stage, 2nd } \\
\text { irrigation }\end{array}$ & $\begin{array}{l}\text { Feekes } 7- \\
8 \text { stage, 3rd } \\
\text { irrigation }\end{array}$ & Total & & & & & & & \\
\hline 1 & 0 & 0 & - & - & 0 & & & 1.52 & 31.9 & & & \\
\hline 2 & 60 & 60 & - & - & 120 & & & 4.35 & 103.2 & 23.6 & 59.2 & 39.9 \\
\hline 3 & 75 & 75 & - & - & 150 & & & 4.41 & 110.3 & 19.3 & 52.3 & 37.1 \\
\hline 4 & 60 & 0 & $17^{\mathrm{a}}$ & - & 77 & 3.25 & 1.16 & 3.66 & 73.1 & 27.8 & 53.2 & 52.2 \\
\hline 5 & 80 & 0 & $12^{\mathrm{a}}$ & - & 92 & 3.52 & 1.11 & 3.80 & 87.8 & 24.8 & 60.9 & 40.7 \\
\hline 6 & 100 & 0 & $10^{\mathrm{a}}$ & - & 110 & 3.61 & 1.09 & 4.20 & 95.2 & 24.4 & 57.3 & 42.5 \\
\hline 7 & 40 & 40 & $3^{a}$ & - & 83 & 4.02 & 1.02 & 3.81 & 88.5 & 27.6 & 68.1 & 40.6 \\
\hline 8 & 50 & 50 & $0^{\mathrm{a}}$ & - & 100 & 4.30 & 0.98 & 4.32 & 98.8 & 28.0 & 67.0 & 41.8 \\
\hline 9 & 60 & 60 & $0^{\mathrm{a}}$ & - & 120 & 4.20 & 0.99 & 4.39 & 105.4 & 23.9 & 61.3 & 39.3 \\
\hline 10 & 60 & 0 & - & $29^{\mathrm{a}}$ & 89 & 2.98 & 1.30 & 3.99 & 94.2 & 27.8 & 69.7 & 39.4 \\
\hline 11 & 80 & 0 & - & $24^{\mathrm{a}}$ & 104 & 3.24 & 1.24 & 4.13 & 97.6 & 25.1 & 63.5 & 40.5 \\
\hline 12 & 100 & 0 & - & $21^{\mathrm{a}}$ & 121 & 3.43 & 1.19 & 4.29 & 102.4 & 22.9 & 58.3 & 39.2 \\
\hline 13 & 40 & 40 & - & $18^{\mathrm{a}}$ & 98 & 3.62 & 1.15 & 4.27 & 100.5 & 28.1 & 70.0 & 39.9 \\
\hline 14 & 50 & 50 & - & $12^{\mathrm{a}}$ & 112 & 3.84 & 1.10 & 4.35 & 108.5 & 25.3 & 68.4 & 36.8 \\
\hline 15 & 60 & 60 & - & $15^{\mathrm{a}}$ & 135 & 3.77 & 1.12 & 4.40 & 115.2 & 21.3 & 61.5 & 34.7 \\
\hline \multicolumn{6}{|c|}{$\operatorname{LSD}(p=0.05)$} & & & 0.367 & 11.04 & 3.03 & 9.52 & 4.41 \\
\hline
\end{tabular}

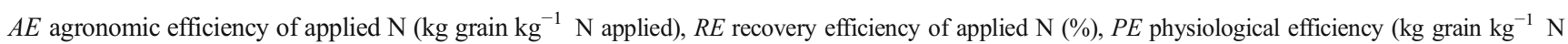
uptake), $Y P_{0}$ yield potential with no additional fertilizer $\mathrm{N}$ applied, $R I$ response index, $\mathrm{RI}_{\mathrm{NDVI}}, L S D$ least significant difference

${ }^{\mathrm{a}}$ GreenSeeker-guided N application

${ }^{\mathrm{b}}$ Crown root initiation stage 
Table 5 Evaluation of GreenSeeker-based N management in wheat (cultivar PBW 343) at Karnal, India during 2006-2007

\begin{tabular}{|c|c|c|c|c|c|c|c|c|c|c|c|c|}
\hline \multirow[t]{2}{*}{ Treatment } & \multicolumn{5}{|c|}{ Fertilizer $\mathrm{N}$ application $\left(\mathrm{kg} \mathrm{N} \mathrm{ha}^{-1}\right)$} & \multirow{2}{*}{$\begin{array}{l}\mathrm{YP}_{0} \\
\left(\mathrm{Mg} \mathrm{ha}^{-1}\right)\end{array}$} & \multirow[t]{2}{*}{ RI } & \multirow{2}{*}{$\begin{array}{l}\text { Grain yield } \\
\left(\mathrm{Mg} \mathrm{ha}^{-1}\right)\end{array}$} & \multirow{2}{*}{$\begin{array}{l}\text { Total N uptake } \\
\left(\mathrm{kg} \mathrm{ha}^{-1}\right)\end{array}$} & \multirow[t]{2}{*}{$\mathrm{AE}$} & \multirow[t]{2}{*}{ RE (\%) } & \multirow[t]{2}{*}{$\mathrm{PE}$} \\
\hline & $\begin{array}{l}\text { Basal at } \\
\text { sowing }\end{array}$ & $\begin{array}{l}\text { CRI, 1st } \\
\text { irrigation }\end{array}$ & $\begin{array}{l}\text { Feekes 5-6 } \\
\text { stage, 2nd } \\
\text { irrigation }\end{array}$ & $\begin{array}{l}\text { Feekes } 7- \\
8 \text { stage, 3rd } \\
\text { irrigation }\end{array}$ & Total & & & & & & & \\
\hline 1 & 0 & 0 & - & - & 0 & & & 1.89 & 39.2 & & & \\
\hline 2 & 75 & 75 & - & - & 150 & & & 4.56 & 138.3 & 17.8 & 66.1 & 26.9 \\
\hline 3 & 80 & 0 & $25^{\mathrm{a}}$ & - & 105 & 3.56 & 1.19 & 4.01 & 107.7 & 20.2 & 65.2 & 31.3 \\
\hline 4 & 100 & 0 & $20^{\mathrm{a}}$ & - & 120 & 3.76 & 1.14 & 4.10 & 119.8 & 18.4 & 67.2 & 27.4 \\
\hline 5 & 40 & 40 & $25^{\mathrm{a}}$ & - & 105 & 3.61 & 1.19 & 4.24 & 115.5 & 22.4 & 72.7 & 30.8 \\
\hline 6 & 50 & 50 & $19^{\mathrm{a}}$ & - & 119 & 3.82 & 1.13 & 4.34 & 121.2 & 20.6 & 68.9 & 29.9 \\
\hline 7 & 60 & 60 & $17^{\mathrm{a}}$ & - & 137 & 3.88 & 1.12 & 4.43 & 133.9 & 18.5 & 69.1 & 26.8 \\
\hline 8 & 80 & 0 & - & $37^{\mathrm{a}}$ & 117 & 3.50 & 1.29 & 4.21 & 113.2 & 19.8 & 63.2 & 31.4 \\
\hline 9 & 100 & 0 & - & $32^{\mathrm{a}}$ & 132 & 3.59 & 1.24 & 4.43 & 126.9 & 19.2 & 66.4 & 29.0 \\
\hline 10 & 40 & 40 & - & $29^{\mathrm{a}}$ & 109 & 3.58 & 1.22 & 4.47 & 112.0 & 23.7 & 66.8 & 35.4 \\
\hline 11 & 50 & 50 & - & $23^{\mathrm{a}}$ & 123 & 3.78 & 1.16 & 4.35 & 126.5 & 18.5 & 65.6 & 28.2 \\
\hline 12 & 60 & 60 & - & $13^{\mathrm{a}}$ & 133 & 3.91 & 1.09 & 4.45 & 131.1 & 19.2 & 69.1 & 27.9 \\
\hline \multicolumn{6}{|c|}{$\operatorname{LSD}(p=0.05)$} & & & 0.423 & 10.11 & 3.29 & 7.45 & 5.00 \\
\hline
\end{tabular}

$A E$ agronomic efficiency of applied $\mathrm{N}\left(\mathrm{kg}_{\text {grain }} \mathrm{kg}^{-1} \mathrm{~N}\right.$ applied), $R E$ recovery efficiency of applied $\mathrm{N}(\%), P E$ physiological efficiency $\left(\mathrm{kg}\right.$ grain $\mathrm{kg}^{-1} \mathrm{~N}$ uptake), $Y P_{0}$ yield potential with no additional fertilizer $\mathrm{N}$ applied, $R I$ response index, $\mathrm{RI}_{\mathrm{NDVI}}, L S D$ least significant difference

${ }^{\mathrm{a}}$ GreenSeeker-guided N application

${ }^{\mathrm{b}}$ Crown root initiation stage

Table 6 Evaluation of GreenSeeker-based N management in wheat (cultivar PBW 343) at Modipuram, India during 2006-2007

\begin{tabular}{|c|c|c|c|c|c|c|c|c|c|c|c|c|}
\hline \multirow[t]{2}{*}{ Treatment } & \multicolumn{5}{|c|}{ Fertilizer $\mathrm{N}$ application $\left(\mathrm{kg} \mathrm{N} \mathrm{ha}^{-1}\right)$} & \multirow{2}{*}{$\begin{array}{l}\mathrm{YP}_{0} \\
\left(\mathrm{Mg} \mathrm{ha}^{-1}\right)\end{array}$} & \multirow[t]{2}{*}{ RI } & \multirow{2}{*}{$\begin{array}{l}\text { Grain yield } \\
\left(\mathrm{Mg} \mathrm{ha}^{-1}\right)\end{array}$} & \multirow{2}{*}{$\begin{array}{l}\text { Total N uptake } \\
\left(\mathrm{kg} \mathrm{ha}^{-1}\right)\end{array}$} & \multirow[t]{2}{*}{$\mathrm{AE}$} & \multirow[t]{2}{*}{$\mathrm{RE}(\%)$} & \multirow[t]{2}{*}{$\mathrm{PE}$} \\
\hline & $\begin{array}{l}\text { Basal at } \\
\text { sowing }\end{array}$ & $\begin{array}{l}\text { CRI, 1st } \\
\text { irrigation }\end{array}$ & $\begin{array}{l}\text { Feekes } 5-6 \\
\text { stage, 2nd } \\
\text { irrigation }\end{array}$ & $\begin{array}{l}\text { Feekes } 7- \\
8 \text { stage, 3rd } \\
\text { irrigation }\end{array}$ & Total & & & & & & & \\
\hline 1 & 0 & 0 & - & - & 0 & & & 1.46 & 33.8 & & & \\
\hline 2 & 60 & 60 & - & - & 120 & & & 5.26 & 118.2 & 31.7 & 70.3 & 45.3 \\
\hline 3 & 75 & 75 & - & - & 150 & & & 5.57 & 130.1 & 27.4 & 64.2 & 43.1 \\
\hline 4 & 60 & 0 & $19^{\mathrm{a}}$ & - & 79 & 2.98 & 1.17 & 3.74 & 84.9 & 28.9 & 64.7 & 44.3 \\
\hline 5 & 80 & 0 & $15^{\mathrm{a}}$ & - & 95 & 3.44 & 1.12 & 4.57 & 99.5 & 32.7 & 69.2 & 47.7 \\
\hline 6 & 100 & 0 & $11^{\mathrm{a}}$ & - & 111 & 3.96 & 1.08 & 4.96 & 111.8 & 31.5 & 70.3 & 45.5 \\
\hline 7 & 40 & 40 & $9^{a}$ & - & 89 & 3.58 & 1.07 & 4.30 & 91.5 & 31.9 & 64.8 & 49.2 \\
\hline 8 & 50 & 50 & $7^{\mathrm{a}}$ & - & 107 & 4.44 & 1.04 & 5.27 & 103.3 & 35.6 & 65.0 & 54.8 \\
\hline 9 & 60 & 60 & $4^{\mathrm{a}}$ & - & 124 & 4.65 & 1.02 & 5.53 & 121.8 & 32.8 & 71.0 & 46.3 \\
\hline 10 & 60 & 0 & - & $24^{\mathrm{a}}$ & 84 & 2.84 & 1.23 & 3.68 & 93.9 & 26.4 & 71.5 & 36.9 \\
\hline 11 & 80 & 0 & - & $21^{\mathrm{a}}$ & 101 & 3.66 & 1.16 & 4.52 & 101.5 & 30.3 & 67.0 & 45.2 \\
\hline 12 & 100 & 0 & - & $18^{\mathrm{a}}$ & 118 & 4.10 & 1.12 & 4.73 & 118.8 & 27.7 & 72.0 & 39.0 \\
\hline 13 & 40 & 40 & - & $18^{\mathrm{a}}$ & 98 & 3.64 & 1.13 & 4.39 & 101.2 & 29.9 & 68.8 & 43.8 \\
\hline 14 & 50 & 50 & - & $14^{\mathrm{a}}$ & 114 & 4.70 & 1.08 & 5.42 & 108.8 & 34.7 & 65.8 & 52.8 \\
\hline 15 & 60 & 60 & - & $10^{\mathrm{a}}$ & 130 & 4.88 & 1.06 & 5.60 & 122.4 & 31.8 & 68.2 & 46.7 \\
\hline \multicolumn{6}{|c|}{$\operatorname{LSD}(p=0.05)$} & & & 1.109 & 9.52 & 9.03 & 7.43 & 14.81 \\
\hline
\end{tabular}

$A E$ agronomic efficiency of applied $\mathrm{N}\left(\mathrm{kg}_{\text {grain }} \mathrm{kg}^{-1} \mathrm{~N}\right.$ applied), $R E$ recovery efficiency of applied $\mathrm{N}(\%), P E$ physiological efficiency (kg grain $\mathrm{kg}^{-1} \mathrm{~N}$ uptake), $Y P_{0}$ yield potential with no additional fertilizer $\mathrm{N}$ applied, $R I$ response index, $\mathrm{RI}_{\mathrm{NDVI}}, L S D$ least significant difference

${ }^{\mathrm{a}}$ GreenSeeker-guided N application

${ }^{\mathrm{b}}$ Crown root initiation stage 
Table 7 Evaluation of GreenSeeker-based N management in wheat (cultivar PBW 343) at Ludhiana, India during 2006-2007

\begin{tabular}{|c|c|c|c|c|c|c|c|c|c|c|c|c|}
\hline \multirow[t]{2}{*}{ Treatment } & \multicolumn{5}{|c|}{ Fertilizer $\mathrm{N}$ application $\left(\mathrm{kg} \mathrm{N} \mathrm{ha}^{-1}\right)$} & \multirow{2}{*}{$\begin{array}{l}\mathrm{YP}_{0} \\
\left(\mathrm{Mg} \mathrm{ha}^{-1}\right)\end{array}$} & \multirow[t]{2}{*}{ RI } & \multirow{2}{*}{$\begin{array}{l}\text { Grain yield } \\
\left(\mathrm{Mg} \mathrm{ha}^{-1}\right)\end{array}$} & \multirow{2}{*}{$\begin{array}{l}\text { Total N uptake } \\
\left(\mathrm{kg} \mathrm{ha}^{-1}\right)\end{array}$} & \multirow[t]{2}{*}{$\mathrm{AE}$} & \multirow[t]{2}{*}{ RE $(\%)$} & \multirow[t]{2}{*}{ PE } \\
\hline & $\begin{array}{l}\text { Basal at } \\
\text { sowing }\end{array}$ & $\begin{array}{l}\text { CRI, 1st } \\
\text { irrigation }\end{array}$ & $\begin{array}{l}\text { Feekes } 5-6 \\
\text { stage, 2nd } \\
\text { irrigation }\end{array}$ & $\begin{array}{l}\text { Feekes } 7- \\
8 \text { stage, 3rd } \\
\text { irrigation }\end{array}$ & Total & & & & & & & \\
\hline 1 & 0 & 0 & - & - & 0 & & & 1.79 & 33.4 & - & - & - \\
\hline 2 & 60 & 60 & - & - & 120 & & & 4.57 & 103.3 & 23.2 & 58.3 & 39.7 \\
\hline 3 & 60 & 0 & $30^{\mathrm{a}}$ & - & 90 & 2.62 & 1.31 & 4.01 & 79.8 & 24.7 & 51.6 & 47.7 \\
\hline 4 & 90 & 0 & $10^{\mathrm{a}}$ & - & 100 & 3.56 & 1.08 & 4.49 & 96.8 & 27.0 & 63.4 & 42.6 \\
\hline 5 & 30 & 30 & $24^{\mathrm{a}}$ & - & 84 & 2.98 & 1.22 & 3.87 & 73.9 & 24.8 & 48.2 & 51.5 \\
\hline 6 & 60 & 30 & $13^{\mathrm{a}}$ & - & 103 & 3.45 & 1.04 & 4.41 & 96.8 & 25.4 & 63.5 & 40.0 \\
\hline 7 & 45 & 45 & $21^{\mathrm{a}}$ & - & 111 & 3.32 & 1.17 & 4.45 & 97.1 & 24.0 & 57.4 & 41.8 \\
\hline 8 & 60 & 45 & $13^{\mathrm{a}}$ & - & 118 & 3.45 & 1.11 & 4.56 & 103.6 & 23.5 & 59.5 & 39.5 \\
\hline 9 & 60 & 60 & $0^{\mathrm{a}}$ & - & 120 & 3.88 & 1.01 & 4.59 & 108.8 & 23.3 & 62.8 & 37.2 \\
\hline 10 & 60 & 0 & - & $27^{\mathrm{a}}$ & 87 & 2.97 & 1.25 & 3.76 & 80.9 & 22.6 & 54.6 & 42.5 \\
\hline 11 & 90 & 0 & - & $23^{\mathrm{a}}$ & 113 & 3.19 & 1.20 & 4.24 & 91.0 & 21.7 & 51.0 & 42.5 \\
\hline 12 & 30 & 30 & - & $31^{\mathrm{a}}$ & 91 & 2.72 & 1.31 & 4.05 & 86.5 & 24.8 & 58.4 & 42.6 \\
\hline 13 & 60 & 30 & - & $10^{\mathrm{a}}$ & 100 & 3.44 & 1.09 & 4.48 & 99.8 & 26.9 & 66.4 & 40.5 \\
\hline 14 & 45 & 45 & - & $15^{\mathrm{a}}$ & 105 & 3.61 & 1.13 & 4.53 & 103.2 & 26.1 & 66.5 & 39.3 \\
\hline 15 & 60 & 45 & - & $14^{\mathrm{a}}$ & 119 & 3.64 & 1.11 & 4.48 & 99.7 & 22.6 & 55.7 & 40.7 \\
\hline 16 & 60 & 60 & - & $0^{\mathrm{a}}$ & 120 & 4.27 & 1.01 & 4.54 & 106.2 & 22.9 & 60.7 & 37.7 \\
\hline \multicolumn{8}{|c|}{$\operatorname{LSD}(p=0.05)$} & 0.513 & 8.7 & 3.71 & 9.34 & 5.71 \\
\hline
\end{tabular}

$A E$ agronomic efficiency of applied $\mathrm{N}\left(\mathrm{kg}_{\text {grain }} \mathrm{kg}^{-1} \mathrm{~N}\right.$ applied), $R E$ recovery efficiency of applied $\mathrm{N}(\%), P E$ physiological efficiency $\left(\mathrm{kg}_{\text {grain }} \mathrm{kg}^{-1} \mathrm{~N}\right.$ uptake), $Y P_{0}$ yield potential with no additional fertilizer $\mathrm{N}$ applied, $R I$ response index, $\mathrm{RI}_{\mathrm{NDV}}, L S D$ least significant difference

${ }^{\mathrm{a}}$ GreenSeeker-guided N application

${ }^{\mathrm{b}}$ Crown root initiation stage

prescriptive doses of $\mathrm{N}$ at planting and crown root initiation stage, $\mathrm{RI}_{\mathrm{NDVI}}$ values turned out to be higher at Feekes 7-8 stage than at Feekes 5-6 stage. It can also be interpreted that optical sensor underestimates the fertilizer $\mathrm{N}$ needs of wheat when it is used too close to a fertilizer $\mathrm{N}$ application event. For example, when total prescriptive dose of $\mathrm{N}$ was applied at planting, the amount of fertilizer $\mathrm{N}$ to be applied as guided by GreenSeeker optical sensor turned out to be higher than when similar amount of $\mathrm{N}$ was applied in two equal split doses at planting and crown root initiation stage. Of course, the amount of $\mathrm{N}$ recommended by the optical sensor was very sensitive to the total amount of $\mathrm{N}$ already applied to wheat. The more was the total amount of $\mathrm{N}$ applied at planting and crown root initiation stage; less was the recommendation of fertilizer $\mathrm{N}$ given by the optical sensor. In Tables 4, 5, 6, and 7, when only 60 or $80 \mathrm{~kg} \mathrm{~N}$ ha $^{-1}$ was applied at planting and no $\mathrm{N}$ was applied at crown root initiation stage, optical sensor-guided recommendations were under estimated. Thus total fertilizer $\mathrm{N}$ applications in these treatments turned out to be less than in treatments with $100 \mathrm{~kg} \mathrm{~N} \mathrm{ha}^{-1}$ or more applied either all at planting or in two split doses. It was possibly due to that fact that at low prescriptive $\mathrm{N}$ levels, $\mathrm{YP}_{0}$ turned out to be less whereas $\mathrm{RI}_{\mathrm{NDVI}}$ did not turn out to be proportionately high. Since fertilizer $\mathrm{N}$ dose is calculated from the difference of $\mathrm{YP}_{n}$ and $\mathrm{YP}_{0}$, the total fertilizer recommendation (prescriptive+ optical sensor guided) remained low than when adequate amount of fertilizer $\mathrm{N}$ was applied as prescriptive dose.

The correlation between $\mathrm{RI}_{\mathrm{NDVI}}$ and agronomic efficiency as reported by Raun et al. (2002) was not observed in the present study (Tables 4, 5, 6, and 7). It was primarily due to the manner in which prescriptive doses of $\mathrm{N}$ are applied before applying a corrective $\mathrm{N}$ dose as guided by GreenSeeker optical sensor in the irrigated wheat in the IndoGangetic Plain. While $\mathrm{RI}_{\mathrm{NDVI}}$ computed on the day of applying a corrective dose of $\mathrm{N}$ was strongly influenced both by quantity and time of $\mathrm{N}$ application in the prescriptive doses, the agronomic or N-use efficiency was determined by amount of total $\mathrm{N}$ applied both as prescriptive and corrective $\mathrm{N}$ doses.

The N-use efficiency factor used in the $\mathrm{N}$ correction algorithm for using GreenSeeker optical sensor has been arbitrarily fixed at 0.5 keeping in view that $\mathrm{N}$-use efficiency for irrigated wheat at on-farm locations in the Indo-Gangetic Plain is generally less than $50 \%$ (Singh et al. 2007). It may be fine tuned as more data are generated in the years to come. Since efficiency factor as used in the fertilizer nitrogen optimization algorithm pertains only to the corrective $\mathrm{N}$ 
dose, one should be able to set its value as high as 0.7 , but its validity needs to be checked by further experimentation.

\subsection{Evaluation of GreenSeeker-guided N management vis-à-vis blanket recommendation}

Application of $120 \mathrm{~kg} \mathrm{~N} \mathrm{ha}^{-1}$ in two equal split doses at planting and the crown root initiation stage of irrigated wheat constitutes the blanket recommendation in the Indian state of Punjab where Ludhiana site is located. In the neighboring states of Haryana and Uttar Pradesh where the other two sites-Karnal and Modipuram-are located, the recommendation is to apply $150 \mathrm{~kg} \mathrm{~N}^{-1}$ (Yadvinder-Singh et al. 2007). Thus, different GreenSeeker optical sensorbased fertilizer $\mathrm{N}$ management scenarios in wheat as listed in Tables 4, 5, 6, and 7 were evaluated vis-à-vis blanket recommendations of 120 and $150 \mathrm{~kg} \mathrm{~N} \mathrm{ha}^{-1}$. Application of fertilizer $\mathrm{N}$ in two equal split doses-half at sowing and half at crown root initiation stage (along with first irrigation) has been found beneficial in increasing grain yield and $\mathrm{N}$ uptake of wheat, and it is a general recommendation for wheat over a vast area in the IndoGangetic Plain (Meelu et al. 1987). Nitrogen uptake of irrigated wheat proceeds very slowly until tillering begins, and $\mathrm{N}$ flux $\left(\mathrm{kg} \mathrm{N} \mathrm{ha}{ }^{-1}\right.$ day $^{-1}$ ) increases to a maximum around Feekes 6 stage (Doerge et al. 1991). Also, N management in irrigated wheat should not only consider crop demand but also the specific irrigation schedule that is followed. Fertilizer $\mathrm{N}$ applied at a time when crop needs are high, reduces the chances of losses of $\mathrm{N}$ from the soil-plant system, thus, improving N-use efficiency. Reduction in losses of ${ }^{15} \mathrm{~N}$ applied as urea to wheat in the Indo-Gangetic Plain through synchronization with irrigation events has been reported by Katyal et al. (1987). Therefore, a number of prescriptive $\mathrm{N}$ management scenarios consisting of applying 60 to $120 \mathrm{~kg} \mathrm{Nha}^{-1}$ either at planting or in two split doses at planting and the crown root initiation stage combined with corrective $\mathrm{N}$ management scenarios as guided by GreenSeeker optical sensor at Feekes 5-6 (second irrigation) or Feekes 7-8 (third irrigation) stage were tested at the three locations in the western IndoGangetic Plain. Since at planting of wheat there are no plants and at crown root initiation stage (about 3 weeks after planting) biomass is too little, optical sensor cannot be used for guiding fertilizer $\mathrm{N}$ application at these stages.

Data from the four experiments conducted during 20052006 and 2006-2007 seasons at Ludhiana, Karnal, and Modipuram as listed in Tables 4, 5, 6, and 7 reveal that GreenSeeker optical sensor can be successfully used to guide fertilizer $\mathrm{N}$ applications to irrigated wheat in the western Indo-Gangetic Plain at Feekes 5-6 and Feekes 7-8 stages coinciding with 2 nd and 3rd irrigation events provided an appropriate prescriptive $\mathrm{N}$ management strat- egy is adopted. Optical sensor-guided fertilizer N applications were tested both with single (at planting only) and two doses (at planting and crown root initiation stage) of prescriptive $\mathrm{N}$ management scenarios. Applying a single prescriptive dose of fertilizer $\mathrm{N}$ at planting before applying a sensor-guided fertilizer $\mathrm{N}$ dose was tried because many farmers will not like to switch to application of fertilizers to wheat in 3 split doses from the blanket recommendation of applying fertilizer in two doses. When $60 \mathrm{~kg} \mathrm{~N} \mathrm{ha}^{-1}$ was applied at planting and no $\mathrm{N}$ was applied at crown root initiation stage of wheat, optical sensor-guided fertilizer $\mathrm{N}$ applications at Feekes 5-6 or Feekes 7-8 stage were never adequate to produce optimum wheat yields. Both at Ludhiana and Modipuram (Tables 4, 6, and 7), the grain yield of wheat was significantly less than that produced by following the blanket recommendation. It was due to the fact that total fertilizer $\mathrm{N}$ application (prescriptive + sensor guided) ranged from 77 to $90 \mathrm{~kg} \mathrm{~N} \mathrm{ha}^{-1}$ as compared with the 120 and $150 \mathrm{~kg} \mathrm{Nha}^{-1}$ in the blanket recommendation. This scenario is developed because low $\mathrm{YP}_{0}$ are recorded when low levels of fertilizer $\mathrm{N}$ are applied at planting of wheat. Even with the application of $80 \mathrm{~kg} \mathrm{~N} \mathrm{ha}^{-1}$ at planting and no $\mathrm{N}$ at crown root initiation stage at Karnal during 2006-2007 and at Ludhiana during 2005-2006, similar trend was observed (Tables 4 and 5). At Modipuram too, the grain yield obtained by applying $80 \mathrm{~kg} \mathrm{~N} \mathrm{ha}^{-1}$ at planting along with an optical sensor-guided dose at 2 nd or 3 rd irrigation stage resulted in lower yields than produced by applying the blanket recommendation of $150 \mathrm{~kg} \mathrm{~N} \mathrm{ha}^{-1}$, though the differences were not statistically significant. It suggests that application of one optical sensor-guided $\mathrm{N}$ dose at 2 nd or 3rd irrigation event will not work when only one prescriptive $\mathrm{N}$ dose of $80 \mathrm{~kg} \mathrm{~N} \mathrm{ha}^{-1}$ or less is applied at planting. Application of at least $90 \mathrm{~kg} \mathrm{~N} \mathrm{ha}^{-1}$ at planting of wheat resulted in $\mathrm{YP}_{0}$ values high enough to obtain wheat yields equivalent to those recorded with blanket fertilizer $\mathrm{N}$ recommendation provided these are supplemented with application of corrective $\mathrm{N}$ doses as guided by GreenSeeker optical sensor at $2 \mathrm{nd}$ or 3 rd irrigation stages.

Prescriptive $\mathrm{N}$ management scenarios consisting of applying fertilizer $\mathrm{N}$ dose of 45 or $50 \mathrm{~kg} \mathrm{~N} \mathrm{ha}^{-1}$ both at planting and at crown root initiation stage work better with optical sensor-guided corrective $\mathrm{N}$ management at Feekes $5-6$ or Feekes $7-8$ stages. But application of $80 \mathrm{~kg} \mathrm{~N}^{-1}$ or less did not work well even when the total amount was applied in two equal split doses at planting and at crown root initiation stage. For example, in Ludhiana 2005-2006 and Modipuram 2006-2007 experiments (Tables 4 and 6) the prescriptive dose of $80 \mathrm{~kg} \mathrm{~N} \mathrm{ha}^{-1}$ along with sensorguided $\mathrm{N}$ application at Feekes 5-6 stage resulted in production of significantly less grain yield of wheat than in the treatment receiving the blanket recommendation. At Modipuram (Table 6) the strategy of applying $40 \mathrm{~kg} \mathrm{~N} \mathrm{ha}^{-1}$ 
both at planting and crown root initiation stage did not work even when optical sensor-guided dose was applied at Feekes 7-8 stage. A perusal of the data in all the four evaluation experiments (Tables $4,5,6$, and 7), revealed that at 45 to $50 \mathrm{~kg} \mathrm{~N} \mathrm{ha}^{-1}$ must be applied both at planting and at crown root initiation stage before applying an optical sensor-guided dose at Feekes $5-6$ or Feekes 7-8 stage of wheat. This observation is in line with already published research on $\mathrm{N}$ nutrition of wheat. In a field study in Mexico, Ortiz-Monasterio et al. (1994) observed that a three-way-split application of fertilizer $\mathrm{N}$ to wheat with one third at planting, one third at Feekes 6 stage (Zadok's scale Z31) and one third at Feekes 8 (flag leaf just visible, Z37) resulted in optimum grain yield of wheat. These experiments were conducted in heavy clay soils. It is expected that in lighter textured soils, with potentially higher leaching problems, the three- or four-way split could be more efficient than the two-way split (Chaudhary and Katoch 1981). In a study carried out by International Atomic Energy Agency (IAEA) on irrigated wheat in ten countries, it was found that $\mathrm{N}$ recovery in wheat was higher with fertilizer $\mathrm{N}$ application at Feekes 6 stage rather than at planting (IAEA 2000). The study concluded that most of the $\mathrm{N}$ should be applied by Feekes 6 stage to maximize grain yield and $N$ application should not be delayed beyond Feekes 8 stage.

Data listed in Tables 4, 5, 6, and 7 suggest that increased fertilizer $\mathrm{N}$-use efficiency at optimum yield levels was observed due to lower rates of total $\mathrm{N}$ application as compared with blanket recommendations when appropriate prescriptive fertilizer $\mathrm{N}$ applications strategies are combined with a GreenSeeker optical sensor-guided fertilizer $\mathrm{N}$ application at 2 nd or 3rd irrigation stages. However, this reduction in total $\mathrm{N}$ application cannot be used as a clue for formulating another blanket recommendation consisting of moderate doses of $\mathrm{N}$ at planting and first irrigation stages and a small dose of $\mathrm{N}$ during Feekes 5 to 8 stages. A look at data pertaining to corrective $\mathrm{N}$ doses worked out by using GreenSeeker optical sensor and the grain yields of wheat (Tables 4, 5, 6, and 7) reveals that for different variants of moderate prescriptive $\mathrm{N}$ doses, the corrective $\mathrm{N}$ dose for obtaining high yield levels was determined by the timing of prescriptive $\mathrm{N}$ doses as well as time of application of corrective $\mathrm{N}$ dose. Thus, a new blanket recommendation can be formulated and gadgets like GreenSeeker optical sensor will have to be employed for field-specific management of $\mathrm{N}$ in irrigated wheat in the Indo-Gangetic Plains of South Asia. Recently, Li et al. (2009) reported the usefulness of GreenSeeker optical sensor in significantly improving the N-use efficiency of winter wheat in China. As compared to farmers' practice of applying more than $300 \mathrm{~kg} \mathrm{~N} \mathrm{ha}^{-1}$, mean optical sensor-guided $\mathrm{N}$ application at 30 on-farm locations turned out to be only $61 \mathrm{~kg} \mathrm{~N}$ ha $^{-1}$ but with similar yield level.
In the present investigation, removal of $\mathrm{N}$ by wheat was generally determined by the total quantity of fertilizer $\mathrm{N}$ applied in different treatment plots (Tables 4, 5, 6, and 7). High fertilizer $\mathrm{N}$-use efficiency parameters such as recovery efficiency and agronomic efficiency were observed in all those treatments (Tables 4, 5, 6, and 7) where high yields were recorded by applying moderate amount of fertilizer $\mathrm{N}$ at planting and at crown root initiation stages as prescriptive doses and application of need based fertilizer $\mathrm{N}$ doses as guided by GreenSeeker optical sensor followed.

\section{Conclusions}

For irrigated wheat grown in the Indo-Gangetic Plain of South Asia GreenSeeker optical sensor can reliably predict the yield potential of the crop through in-season measurement of the NDVI at Feekes 5-6 or Feekes 7-8 stage Using yield potential and response index worked out from in-season NDVI measurements of the test field and an N-rich strip, fertilizer $\mathrm{N}$ dose to be applied at Feekes 5-6 or 7-8 stage of wheat can be computed as per need of the crop in a particular field and season. However, innovative fertilizer management practices aimed at efficiently managing $\mathrm{N}$ in irrigated wheat must integrate both prescriptive and corrective strategies because adequate amount of fertilizer $\mathrm{N}$ needs to be applied at planting and/or crown root initiation stage when optical sensor cannot be used. GreenSeeker-guided $\mathrm{N}$ dose can be applied at 2nd or 3rd irrigation event (Feekes 5-6 and Feekes 7-8 stages) in wheat but with carefully designed doses of fertilizer applied at planting and crown root initiation stages of wheat crop. A combination of moderate prescriptive dose of fertilizer $\mathrm{N}$ consisting of either applying $90 \mathrm{~kg} \mathrm{~N}^{-1}$ at planting or 45 to $50 \mathrm{~kg} \mathrm{~N} \mathrm{ha}^{-1}$ both at planting and at crown root initiation stages, and a corrective GreenSeekerguided fertilizer $\mathrm{N}$ application at 2nd or 3rd irrigation events can lead to improved fertilizer N-use efficiency with no reduction in yield through savings in total fertilizer $\mathrm{N}$ application as compared with prevalent blanket recommendations.

Acknowledgments The financial and technical support received from the USDA and encouragement from Dr. Ryan Moore to undertake this study is gratefully acknowledged. The first author acknowledges the financial support received from Indian Council of Agricultural Research (ICAR), New Delhi in the form of National Professor project to continue the work on GreenSeeker optical sensor. Thanks are due to Drs. James Schepers, Arnall Brain, and Bram Govaerts for technical support at different times and useful discussions during the course of the studies. We take the opportunity to thank Punjab Agricultural University (Ludhiana), Directorate of Wheat Research-ICAR (Karnal) and Project Directorate for Cropping System Research-ICAR (Modipuram) for providing the necessary facilities used in conducting the experiments. 


\section{References}

Adhikari C, Bronson KF, Panaullah GM, Regmi AP, Saha PK, Dobermann A, Olk DC, Hobbs PR, Pasuquin E (1999) On-farm $\mathrm{N}$ supply and $\mathrm{N}$ nutrition in the rice-wheat system of Nepal and Bangladesh. Field Crops Res 64:273-286. doi:10.1016/S03784290(99)00063-5

Aparicio N, Villegas D, Araus JL, Casadesús J, Royo C (2002) Relationship between growth traits and spectral vegetation indices in durum wheat. Crop Sci 42:1547-1555. doi:10.2135/ cropsci2002.1547

Báez-González AD, Chen P, Tiscareño-López M, Srinivasan R (2002) Using satellite and field data with crop growth modeling to monitor and estimate maize yield in Mexico. Crop Sci 42:19431949. doi:10.2135/cropsci2002.1943

Baligar VC, Fageria NK, He ZL (2001) Nutrient use efficiency in plants. Commun Soil Sci Plant Anal 32:921-950. doi:10.1081/ CSS-100104098

Bijay-Singh, Yadvinfrt-Singh (2003) Nitrogen management in ricewheat system in the Indo-Gangetic Plain. In: Singh Y, Singh B, Nayyar VK, Jagmohan-Singh (eds) Nutrient management for sustainable rice-wheat cropping system. National Agricultural Technology Project, Indian Council of Agricultural Research, New Delhi, and Punjab Agricultural University, Ludhiana. pp 99-114

Bremner JM (1965a) Total nitrogen. In: Black CA (ed) Methods of soil analysis, part 2. Agronomy monograph 9. American Society of Agronomy, Madison, pp 1149-1178

Bremner JM (1965b) Inorganic forms of nitrogen. In: Black CA (ed) Methods of soil analysis, part 2. Agronomy monograph 9. American Society of Agronomy, Madison, pp 1179-1237

Campbell JB (2002) Introduction to remote sensing, 3rd edn. The Guilford Press, New York

Chaudhary TN, Katoch KK (1981) Fertiliser-N management for wheat in coarse textured soils. Fert News 26(12):36-39

Dobermann A, Witt C, Abdulrachman S, Gines HC, Nagarajan R, Son TT, Tan PS, Wang GH, Chien NV, Thoa VTK, Phung CS, Stalin P, Muthukrishanan P, Ravi V, Babu M, Sethanathan GC, Adviento MAA (2003) Soil fertility and indigenous nutrient supply in irrigated domains of Asia. Agron J 95:913-927. doi:10.2134/agronj2003.0913

Doerge TA, Roth RI, Gardner BR (1991) Nitrogen fertilizer management in Arizona, College of Agriculture, The University of Arizona, Tucson. p 87

Fox RH, Roth GW, Iversen KV, Piekielek WP (1989) Soil and tissue nitrate tests compared for predicting soil nitrogen availability to corn. Agron J 81:971-974. doi:10.2134/agronj1989.000219620 $08100060025 x$

Giller KE, Chalk P, Dobermann A, Hammond L, Heffer P, Ladha JK, Nyamudeza P, Maene L, Ssali H, Freney J (2004) Emerging technologies to increase the efficiency of use of fertilizer nitrogen. In: Mosier AR, Syers JK, Freney J (eds) Agriculture and the nitrogen cycle: assessing the impacts of fertilizer use on food production and the environment, SCOPE 65 (Scientific Committee on Problems of the Environment). Island Press, Washington, pp 35-51

Hong SD, Fox RH, Piekielek WP (1990) Field evaluation of several chemical indexes of soil nitrogen availability. Plant Soil 123:8388. doi:10.1007/BF00009929

IAEA (2000) Optimizing nitrogen fertilizer application in irrigated wheat: Results of a co-ordinated research project organized by the joint FAP/IAEA Division of Nuclear Techniques in Food and Agriculture 1994-1998, IAEA TECDOC-1164. International Atomic Energy Agency, Vienna, p 245

Indian Agricultural Statistics Research Institute (2007) Agricultural Research Data Book, IASRI, Library Avenue, New Delhi. p. 333
Johnson GV, Raun WR (2003) Nitrogen response index as a guide to fertilizer management. J Plant Nutr 26:249-262. doi:10.1081/ PLN-120017134

Justes E, Meynard JM, Mary B, Plénet D (1997) Management of N nutrition: diagnosis using stem base extract: JUBIL method. In: Lemaire G (ed) Diagnosis of the Nitrogen Status in Crops. Springer, Berlin, pp 163-187

Katyal JC, Bijay-Singh, Vlek PLG, Buresh RJ (1987) Efficient nitrogen use as affected by urea application and irrigation sequence. Soil Sci Soc Am J 51:366-370. doi:10.2136/ sssaj1987.03615 995005100020020x

Khosla R, Alley MM (1999) Soil-specific nitrogen management on mid-Atlantic coastal plain soils. Better Crops 83(3):6-7

Kranz WL, Kanwar RS (1995) Spatial distribution of leachate losses due to pre-plant tillage methods. In: Clean water-clean environment-21st century. Proceedings of Conference Working Group on Water Quality, vol 2. American Society of Agricultural Engineering, St Joseph. pp 107-110

Ladha JK, Pathak H, Krupnik TJ, Six J, van Kessel C (2005) Efficiency of fertilizer nitrogen in cereal production: retrospect and prospects, Adv Agron 87:85-156. doi:10.1016/S0065-2113 (05) 87003-8

Large EC (1954) Growth stages in cereals. Plant Pathol 3:128-129

Lemaire G, Gastal F (1997) N uptake and distribution in plant canopies. In: Lemaire $\mathrm{G}$ (ed) Diagnosis of the nitrogen status in crops. Springer, Germany, pp 3-43

Li F, Miao Y, Zhang F, Cui Z, Li R, Chen X, Zhang H, Schrodner J, Raun WR, Jia L (2009) In-season optical sensing improves nitrogen use efficiency for winter wheat. Soil Sci Soc Am J 73:1566-1574. doi:10.2136/sssaj2008.0150

Ma BL, Morrison MJ, Dwyer L (1996) Canopy light reflectance and field greenness to assess nitrogen fertilization and yield of maize. Agron J 88:915-920. doi:10.2134/agronj1996.00021962003600060011x

Ma BL, Lianne LM, Dwyer M, Costa C, Cober ER, Morrison MJ (2001) Early prediction of soybean yield from canopy reflectance measurements. Agron J 93:1227-1234. doi:10.2134/ agronj2001.1227

Magdoff FR, Jokela WE, Fox RH, Griffin GF (1990) A soil test for nitrogen availability in the northeastern United States. Commun Soil Sci Plant Anal 21:1103-1115. doi:10.1080/00103629 009368293

Meelu OP, Saggar S, Maskina MS, Rekhi RS (1987) Time and source of nitrogen application in rice and wheat. J Agril Sci Camb 109:387-391. doi:10.1017/S0021859600080813

Mullen RW, Freeman KW, Raun WR, Johnson GV, Stone ML, Solie JB (2003) Identifying an in-season response index and the potential to increase wheat yield with nitrogen. Agron J 95:347351. doi:10.2134/agronj2003.0347

Olsen SR, Cole CV, Watanabe FS, Dean LA (1954) Estimation of available phosphorus in soils by extraction with sodium bicarbonate, USDA Cir. 939, US Govt. Print Office, Washington

Ortiz-Monasterio JIR, Sayre KD, Pena J, Fischer RA (1994) Improving the nitrogen use efficiency of irrigated spring wheat in the Yaqui Valley of Mexico. Trans 15th World Cong Soil Sci $5 b: 348-349$

Peñuelas J, Gamon JA, Fredeen AL, Merino J, Field CB (1994) Reflectance indices associated with physiological changes in nitrogen- and water-limited sunflower leaves. Remote Sens Environ 48:135-146. doi:10.1016/0034-4257(94)90136-8

Raun WR, Johnson GV, Stone ML, Solie JB, Lukina EV, Thomason WE, Schepers JS (2001) In-season prediction of potential grain yield in winter wheat using canopy reflectance. Agron J 93:131138. doi:10.2134/agronj2001.931131x

Raun WR, Solie JB, Johnson GV, Stone ML, Mullen RW, Freeman KW, Thomason WE, Lukina EV (2002) Improving nitrogen use efficiency in cereal grain production with optical sensing and 
variable rate application. Agron J 94:815-820. doi:10.2134/ agronj 2002.0815

Schröder JJ, Neeteson JJ, Oenema O, Struik PC (2000) Does the crop or the soil indicate how to save nitrogen in maize production? Reviewing the state of the art. Field Crops Res 66:151-164. doi:10.1016/S0378-4290(00)00072-1

Thenkabail PS, Smith RB, DePauw E (2000) Hyperspectral vegetation indices and their relationships with agricultural crop characteristics. Remote Sens Environ 71:158-182. doi:10.1016/S00344257(99)00067-X

Walkley A (1947) A critical examination of a rapid method for determining organic carbon in soils: effect of variations in digestion conditions and of inorganic soil constituents. Soil Sci 63:251-263

Yadvinder-Singh, Bijay-Singh, Ladha JK, Singh JP, Choudhary OP (2007) Enhancing nitrogen use efficiency for sustainable rice-wheat production system in the Indo-Gangetic Plains of India. In: Abrol YP, Raghuram N, Sachdev MS (eds) Agricultural nitrogen use and its environmental implications. I.K. International Publishing House Pvt. Ltd., New Delhi, pp 139-164

Yoshida S, Forno DA, Cock DH, Gomez KA (1976) Laboratory manual for physiological studies of rice, 3rd edn. International Rice Research Institute, Los Baños 